\title{
O MESTRE BOREL: ANCESTRALIDADE NEGRA EM PORTO ALEGRE
}

\author{
Santiago Millan ${ }^{1}$
}

\begin{abstract}
"A antropologia não é outra coisa mais que a busca de um saber e uns desenvolvimentos, (...) Eu quero saber , eu quero saber mas ele não conhece os annais da historia que eu vivi com meus avos, mas só que cada conhecimento que ele adquiriu, ele recebeu, já foi com a visão deles(..) Eu pensava comigo, como que esses brancos vão sabe , o que caramba como e o que é" ( Mestre Borel)
\end{abstract}

A etnografia audiovisual, ou mais especificamente a etno biografia como está catalogada no BIEV - Banco de imagens e Efeitos Visuais - intitulado Mestre Borel: a ancestralidade negra em Porto Alegre, versa sobre a vida do Walter ou Calixto Ferreira, o Mestre Borel em seus percursos, memórias e experiências em Porto alegre e algumas cidades do Brasil (Bahia, Rio de Janeiro, Rio Grande). O mestre Borel, na interação entre o tempo individual e o tempo da cidade, percorre os elementos essenciais da memória coletiva da matriz africana brasileira e porto alegrense.

Escrever uma analise critico sobre o uso da oralidade e a restituição da fala do Outro de uma narrativa etnográfica audiovisual implicou para mim, habituado a compreender e observar o recurso audiovisual simplesmente como técnica na produção de indústrias culturais, uma ruptura com meus limites na interpretação do recurso audiovisual como documento construtor de conhecimento, como documento etnográfico.

O documentário realizado por um grupo de pesquisadores (Rafael Devos, Viviane Vedana, Anelise Gutterrez, Ana Luiza Carvalho da Rocha, entre outros) que desenvolveram e desenvolvem suas pesquisas no marco do BIEV, discorrem grande parte de seus projetos etnográficas observando e analisando as experiências, trajetórias, itinerários urbanos, memória coletiva e formas de sociabilidade dos grupos humanos no mundo urbano contemporâneo, percorrendo etnograficamente as sociedades urbanas (Eckert e Rocha, 2004). Não é de meu interesse aprofundar nestas categorias analíticas, porém são elas as que ordenam a etnografia audiovisual no documentário, de modo que a pesquisa etnográfica adotada pela equipe de antropólogos revela-se como um ato para compreender o Outro.

\footnotetext{
${ }^{1}$ Universidade Federal do Rio Grande do Sul, Brasil.
} 
Uma perturbação que provoca o documentário é perceber a existência de um Outro que no senso comum (o senso comum restringido a minhas interações na cidade) não existe no Rio Grande do Sul. Habituado a escutar a descendência europeia do Estado, a comunidade negra na cidade seria só aquela que migra dos estados do norte para o sul nos processos de deslocamentos rural-urbano, camponês-assalariado que caracterizaram a industrialização nos países da América Latina. Esta memória oficial, que invisibiliza as comunidades negras como sujeitos pertencentes ao território e sua construção, é confrontada pelo documentário. Este confronto, consciente ou não, põe a etnografia audiovisual não só na descoberta de cidade e os grupos sociais que habitam nela, mas também na descoberta da diversidade na cidade. Assim, como o sugerem Eckert e Rocha (2001: 11), o documentário provoca "no "leitor/espectador" o estranhamento dos seus próprios códigos culturais e a descentração de seu lugar no mundo, configurando no corpo do documentário, o próprio processo de descoberta do Outro".

Retomando a fala do início do Mestre Borel, na narrativa audiovisual do documentário se produz um deslocamento do "sujeito suposto saber" (Marcus, George citado por Carvalho, 2001: 118) do antropólogo, que o Mestre Borel critica dizendo: "Eu pensava comigo, como que esses brancos vão saber, o que caramba como e que é”. O início do documentário com essa reflexão do Mestre Borel sobre o papel do antropólogo, desloca esse sujeito suposto saber, para o próprio sujeito pesquisado, para ele mesmo, transformando o Mestre Borel em pesquisador-pesquisado. O destino da palavra não é então mais traduzido de uma forma diferente da fala do sujeito (Certeau, 1982), pois é ele mesmo quem a restitui para nós, mesmo com a mediação das categorias que percorrem o que se entrevê no documentário etnográfico.

\section{Itinerários urbanos do mestre Borel: As transformações da cidade}

O Mestre Borel sulca o lugar desde onde a ancestralidade começa a percorrer a cidade. No que hoje se conhece como Avenida Luís Guaranha, no bairro Cidade Baixa, antes era a Areal da Baronesa, a Baronesa de Gravataí, onde se encontrava "o núcleo negro de Porto Alegre", a ilhota, onde era "o chão do crioulo, o chão de negro". O movimento da caneta no caderno situando o lugar, explicando as ruas que percorriam o lugar, o núcleo. As imagens, no porto, fazendo as ruas, descendo material, socializando na esquina e as fotos de 
descendência, vão indicando a presença de negros nesses espaços, as atividades que desenvolvem, afirmando que sua presença é paralela à construção da cidade, ao reconhecimento que constroem a cidade, que fazem parte dela. A identificação das ruas vão indicando os limites desse espaço onde a sociabilidade negra tinha lugar e ao mesmo tempo vão mostrando as mudanças da cidade, o viaduto da Borges, os limites naturais que configuram o espaço numa ilhota (canais e rios que serviam como ruas naturais).

Os locais da experiência religiosa como referente que compartilha a matriz afro brasileira vá com os deslocamentos do Mestre Borel, inclusive orienta esses processos migratórios. De Porto Alegre para Bahia e da Bahia ao Rio é a experiência religiosa quem o acompanha, o que o faz permanecer num lugar, também com o que aprende. Mas não só os deslocamentos no país, no interior da própria Porto Alegre, nela a experiência religiosa é quem orienta os espaços por onde o mestre Borel percorre a cidade. De Rio de Janeiro para Porto Alegre, ao Bairro Restinga, onde o pessoal do Areal da Baronesa também está, também migrou. O Mestre Borel na Restinga anuncia que o espaço primário foi reformado, sendo desocupado física e parcialmente pelos negros e produzindo processos de migração intra-urbana rumo à periferia da cidade, a comunidade que migra se encontra em lugares diferentes da cidade mantendo relações aqui e lá, ampliando o espaço da identidade compartilhada e seus referentes. Os referentes de lazer e as mudanças deles - o carnaval- e a perpetuidade de outros, o bar naval, são contrastes da cidade e suas tensões provocadas pelas mudanças. A vida urbana, as memórias coletivas da matriz afro, assim como a multiplicidade de estar e viver na cidade se conhecem então pelo narrador, pelo Mestre Borel.

\section{O narrador e o tambor}

Todo tempo, toda memória, toda transformação se justapõe ao que perduram, os ritmos e a ancestralidade. O mestre Borel na interação entre o tempo individual e o tempo da cidade percorre os elementos essenciais da memória coletiva da matriz africana brasileira e porto alegrense. $\mathrm{O}$ som, o tambor, aquela arte que tece ao individuo com o mais profundo de sua ancestralidade é aquilo que representa aos ancestrais, é o que perdura, o imutável, que vá além das transformações do eu e da cidade. O som do tambor que inicia e fecha o documentário faz à narração perdurar. 
O mestre Borel tamboreiro da religão afro-brasileira, é o narrador que com suas mãos visibiliza a experiência e o tempo de prática. Com o toque de cada som vá expressando as significacoes e os sentidos da ancestralidade, o som do tambor, a musicalidade, é uma forma de trazê-los, de fazê-los perdurar todo isto na imagem dele sozinho no quarto com seu tambor na disposicão de um ritual que se quer mostrar solene. É tal vez nestes recortes audiovisuais onde se capta a importança da figura do narrador dele (a exclusividade de alguns conhecimentos), mas tambem a importância do antropólogo como narrador das experiencias do Mestre Borel na cidade. A importância ética de que o evento narrativo fora do momento da narração, permaneça como palavra ouvida (Eckert e Rocha, 2004). Desde a memória individual do Mestre Borel se tece ao tempo a memória coletiva dum grupo social.

\section{Referencias}

CARVALHO, J, J. O olhar etnográfico e a voz subalterna. Horizontes Antropológicos, Porto Alegre, ano 7, n. 15, p. 107-147, julho de 2001.

CERTEAU, Michel. A escrita da Historia. Rio de Janeiro: Forense Universitaria. 1982

ECKERT, c. ; Rocha, A. L. C. O antropólogo na figura do narrador. Revista Habitus, instituto goiano de pré-história e antropologia, universidade católica de Goiás, goiania, v. 1, n. 2, p. 395-420, 2004.

ECKERT Cornelia e Rocha, A, L, C . Imagem recolocada: pensar a imagem como Instrumento de pesquisa e análise do pensamento coletivo. Revista Iluminuras - Publicação Eletrônica do Banco de Imagens e Efeitos Visuais. V. 2. n 3..2001.

O Mestre Borel : a ancestralidade negra em Porto Alegre. Direção: Analise Gutteres. Produção: Ocuspocus Imagens. Porto Alegre. 2010.DVD

Recebido em: 20/07/2013

Aprovado em:10/08/2013 